\title{
HIFU immunotherapy: lessons from animal to clinical studies
}

\author{
Feng Wu \\ From Current and Future Applications of Focused Ultrasound 2014. 4th International Symposium \\ Washington, D.C, USA. 12-16 October 2014
}

\section{Background/introduction}

The ideal cancer therapy not only induces the death of all localized tumor cells, but also activates a systemic antitumor immunity. High intensity focused ultrasound (HIFU) has the potential to be such a treatment, as it can noninvasively ablate a targeted tumor below the skin surface, and may subsequently augment host antitumor immunity.

\section{Methods}

This talk is to introduce increasing animal and clinical evidences linking antitumor immune response to HIFU ablation, review the potential mechanisms, and discuss challenges and opportunities involved in HIFU-enhanced host antitumor immunity.

\section{Results and conclusions}

It is concluded that HIFU immunotherapy may play an important role in preventing local recurrence and metastasis of cancer after HIFU treatment.

Submit your next manuscript to BioMed Central and take full advantage of:

- Convenient online submission

- Thorough peer review

- No space constraints or color figure charges

- Immediate publication on acceptance

- Inclusion in PubMed, CAS, Scopus and Google Scholar

- Research which is freely available for redistribution 